\title{
The importance of ecosystem services for rural inhabitants in a changing cultural landscape in Romania
}

\author{
Tibor Hartel $^{1,2}, \underline{\text { Joern Fischer }}^{2}, \underline{\text { Claudia Câmpeanu }}^{3}, \underline{\text { Andra Ioana Milcu }}^{2}, \underline{\text { Jan Hanspach }}^{2}{\text { and } \underline{\text { Ioan Fazev }}^{4}}^{4}$
}

\begin{abstract}
Many traditional cultural landscapes evolved as coupled social-ecological systems. It is important to understand how such systems navigate novel challenges posed by globalization. To address this issue, we bring together two components of a pilot study carried out in a cultural landscape from Central Romania. The region was affected by major social and economic perturbations in the past century, affecting ethnic composition, community cohesion, land property regimes, and the management of common resources. The first component of our study investigated how rural inhabitants appreciated ecosystem services through questionnaires with 98 people in 30 villages. The second component aimed to assess the perception of people about ongoing changes in their communities through semistructured interviews with 50 people in 5 villages. Rural inhabitants particularly valued provisioning ecosystem services such as firewood, water, and crops, but also healthy soils. Rural communities were characterized by a number of social and economic issues, especially individualism, lack of trust, corruption, and poverty. People from communities with many initiatives, e.g., NGOs, associations, and active individuals, were more optimistic regarding the future of their communities than people from villages with few or no initiatives. A major challenge for cultural landscapes such as those in Central Romania is to find new, meaningful ways to keep the social and ecological systems connected. Otherwise there is a risk that (short-term) socioeconomic interests may impair the provisioning of important ecosystem services.
\end{abstract}

Key Words: change; cultural landscape; Eastern Europe; globalization; rural communities

\section{INTRODUCTION}

Traditional cultural landscapes occur worldwide including in Japan (Takeuchi 2010), India (Ranganathan et al. 2008), China (Liu et al. 2013), and Europe (Solymosi 2011, Molnár 2012, Oteros-Rozas et al. 2013). A special feature of these landscapes is that they evolved as, and often still are, tightly coupled socialecological systems, i.e., rural communities and local ecosystems that are strongly interdependent (Bugalho et al. 2011, Fischer et al. 2012). Tight links between the human and natural systems typically developed over centuries and created a cultural and ecological setting that can be cumulatively termed a 'cultural landscape' (Plieninger and Bieling 2012). Rural societies in traditional cultural landscapes are characterized by a welldeveloped system of ecological knowledge to assess the quality of the goods and services provided by ecosystems and to sustainably manage natural systems (Whiteman and Cooper 2000, Molnár 2012, Oteros-Rozas et al. 2013). Moreover, many traditional rural societies developed a series of individual and collective rules, norms, and behaviours that ensured critical resources were shared by all members of the community (Fischer et al. 2012, Sutcliffe et al. 2013). In many traditional cultural landscapes, sustainable management of natural resources resulted in landscapes with high aesthetic, ecological, and cultural values (Plieninger and Bieling 2012). Many ecosystem components of cultural landscapes directly depend on human use, including internationally protected species, habitats (Halada et al. 2011, Wilson et al. 2012), or specific landscape elements, e.g., wood pastures (Plieninger and Schaar 2008) and drove roads (OterosRozas et al. 2013).

Many traditional cultural landscapes in Europe are rapidly changing. Changes are occurring in social, ethnic, cultural, institutional, and economic spheres (Bell et al. 2009, Plieninger and Bieling 2012, Sutcliffe et al. 2013). These changes in turn can lead to landscape changes such as land-use intensification or land abandonment (see Plieninger and Bieling 2012 for an overview). Moreover, they affect the nature of the relationship between people and the environment (Fischer et al. 2012). Many valuable cultural and ecological elements and ecosystem services may be lost because of these changes (Fischer et al. 2012, Plieninger and Bieling 2012).

Given ongoing change, there is an urgent need to understand how traditional social-ecological systems navigate through the new challenges posed by globalization. Such an understanding is crucial to more realistically assess the limits and possibilities for conserving the rich cultural and ecological heritage in traditional cultural landscapes. Ecosystem services (ES) represent the direct and indirect benefits that people derive from ecosystems (MEA 2005), and therefore they play an important bridging role in connecting human systems with ecological systems (Fischer et al. 2012, Martín-López et al. 2012). Recent studies suggest that exploring the cultural perceptions and preferences toward ecosystem services can be useful to identify the most relevant services to people (Martín-López et al. 2012, Plieninger et al. 2013). This, in turn, can help to anticipate possible changes in the future because typically, there are trade-offs between different ecosystem services, e.g., the enhancement of provisioning services typically causes the decline in many other ecosystem services (Foley et al. 2005).

In this pilot study, we focused on a traditional cultural landscape in Transylvania, Central Romania. The region is regarded as rich in cultural and landscape heritage (sometimes termed an 'historic landscape;' Akeroyd and Page 2007), which is widely agreed as demanding careful conservation management (Mihai Eminescu Trust http://www.mihaieminescutrust.org/content/nd standard. asp?n=82; ADEPT Foundation http://www.fundatia-adept.org/). Our study had two goals: (1) to assess the importance of various ecosystem services for local communities, as perceived by local

${ }^{1}$ Sapientia University, Department of Environmental Sciences, ${ }^{2}$ Institute of Ecology, Leuphana University Lueneburg, ${ }^{3}$ School of Sociology and Social Work, University of Bucharest, ${ }^{4}$ School of Environment/CECHR, University of Dundee 
inhabitants; and (2) to provide a glimpse into historic and recent changes in the local communities, as well as the expectations of the inhabitants regarding the future. In assessing the changing relationship between people and nature, we also assessed which actors were perceived as particularly important in shaping the future of local communities.

\section{METHODS}

Short history of the study area: Transylvanian Saxons

Saxons colonized Transylvania from various parts of Germanspeaking Europe in the $12^{\text {th }}-13^{\text {th }}$ centuries, when it was ruled by Hungary. Although other ethnic groups such as Romanians, Hungarians, and Roma were also present in the region, Saxons was privileged to govern and own the landscapes inhabited by them. In this way, Saxon culture was the social and institutional driver of all major community events in the region. Even decades after the collapse of Saxon formal and informal institutions, Saxon culture continued to live in the memories of many people belonging to other ethnic groups. Therefore a short overview of Saxon history is useful to understand the nature of recent social changes and their potential consequences regarding possible changes in the cultural landscape.

In 1485, the Sächsiche Nationsuniversität, i.e., the university, was constituted at the request of the Saxons. All major strategic decisions were made by this institution. The (evangelic) church and the various types of Nachbarschaften, literally meaning neighborhoods, were important in organizing communities at the local level (Dorner 1910, Baltag 2004). Saxon communities were structured around a large set of norms and rules, which led to many social conflicts being resolved peacefully and informally within this ethnic group (Dorner 1910).

Saxon culture was also reflected in the use of natural resources. For example, forests and pastures were communally owned and managed. This was supported via policy decisions, such as the demarcation of prohibition forests in which wood extraction was prohibited. Forest management was conducted on a scientific basis with many foresters trained in Germany, and often, locals were involved in forest management practices, e.g., as forest guards (Oroszi 2004). Communal pastures were controlled by pastoral committees, and measures to maintain pastures, e.g., regular scrub removal, were agreed upon and carried out by all users (Sutcliffe et al. 2013). There were clear rules regarding different types of livestock and when these were allowed to graze.

In the late $18^{\text {th }}$ century and then again in the $20^{\text {th }}$ century, Transylvania and the Saxon region experienced several major socioeconomic, territorial, and political perturbations (Fischer et al. 2012). These changes led to a gradual weakening of the Saxon institution and ultimately its collapse (Nägler 1992, Baltag 2004). Following agrarian reform in 1945 and subsequent collectivization (1949-1962) imposed by the Romanian communist regime, most farmers in Romania, including the Saxons, lost their individual and communal properties (Nägler 1992, Verdery 2003, Baltag 2004). Many Saxons emigrated to Germany and Austria. Finally, following German reunification and the collapse of the Romanian communist regime in 1989, a last major wave of Saxon emigration occurred, and Saxon houses were increasingly inhabited by members of other ethnic groups, i.e., Romanians, Hungarians, and Roma. Massive changes in property regimes occurred even after 1989: land restitution and widespread privatization occurred in the 1990s, causing, among others, changes in pasture and forest management. Most villages once dominated by Saxons now have none or only a handful of Saxons.

The most common land tenure in traditional Saxon times was communal land management for forests and pastures, although arable fields were individually owned (Dorner 1910, Sutcliffe et al. 2013). Currently there is a high diversity of land tenures, ranging from individual properties, e.g., the arable fields and some parts of forests, to communal pasture lands, and church and state owned lands, e.g., in the case of forests (Fischer et al. 2012, Mikulcak et al. 2013).

Study area and selection of villages

Our study was conducted in the Saxon area of southern Transylvania (Fig. 1). Altitudes range from $\sim 250 \mathrm{~m}$ to $\sim 800 \mathrm{~m}$ above sea level. Land cover is dominated by meadows and pastures ( $\sim 40 \%$ cover), deciduous forests $(\sim 30 \%)$, and arable land $(\sim 15 \%)$. Approximately $5 \%$ of the area is urban or industrial, and other land uses such as orchards and vineyards make up for the remainder. Rural communities are generally small: the average number of inhabitants in the 30 villages subjected to this research was 584 (range 30-1900; Institutul National de Statistica 2011). Villages covered gradients in land covers, with different amounts of forest, arable land, and pasture cover, as well as ethnic composition, e.g., significant presence of Saxons, Romanians, Hungarians, and Roma, and activities by major local actors, such as nongovernment organizations.

Fig. 1. Study region from Central Romania indicating the locations of the 30 focal villages and the villages where ecosystem service (ES) questionnaires were completed. Dots represent the major towns in the region.

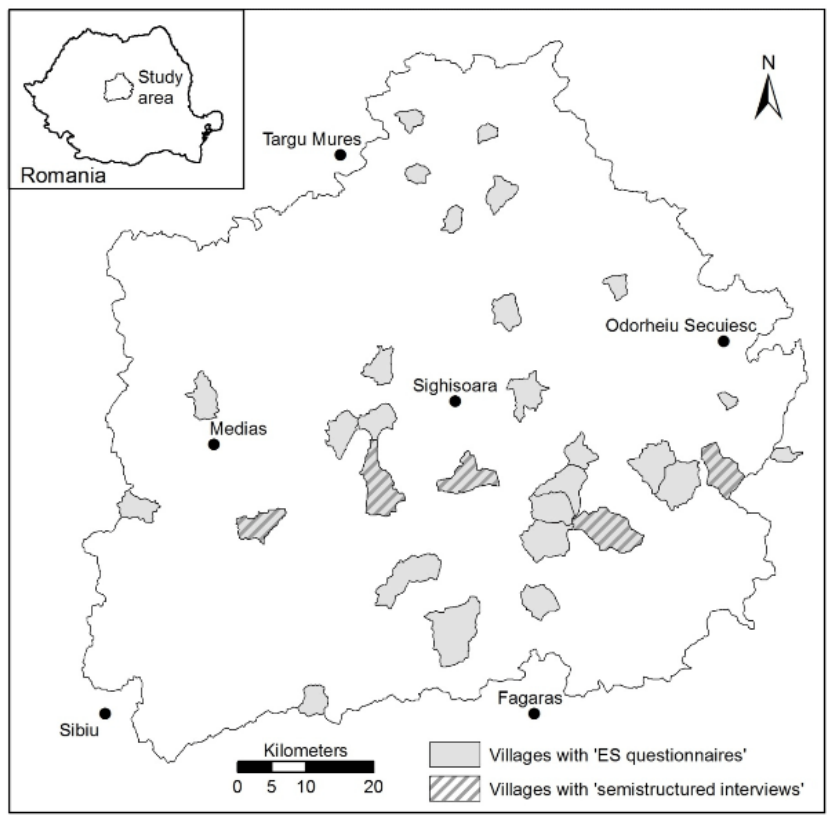


Component 1: questionnaires to assess the perceived importance of ecosystem services

Questionnaire surveys were conducted in 2012 by one person in Romanian. A total of 98 people from 30 villages were asked to complete short questionnaires about ecosystem services (Appendix 1). People were randomly approached in the street as part of a more comprehensive interview exercise. They were asked to rate the importance of 17 different ecosystem services to people in their villages. Ecosystem services included provisioning, supporting, regulating, and aesthetic/cultural services (Fig. 2). These ecosystem services were selected based on the field observations of all authors in 2011 and our previous knowledge. Besides ecosystem services that were obviously important in local communities, e.g., crops and firewood, we also considered ecosystem services that in our perception were used less intensively by local communities, but may nevertheless be important for a significant minority of people, e.g., fishing and hunting. Completing the questionnaire took $\sim 70$ minutes per person. Details about the age, ethnic, gender, and professional structure of the people surveyed are presented in Table 1.

Fig. 2. The importance of ecosystem services for the rural communities. $(\mathrm{P}=$ provisioning service, $\mathrm{S}=$ supporting service, $\mathrm{R}=$ regulating service, $\mathrm{C}=$ cultural service; the number of people responding "I don't know" is given on the right side of the figure.)

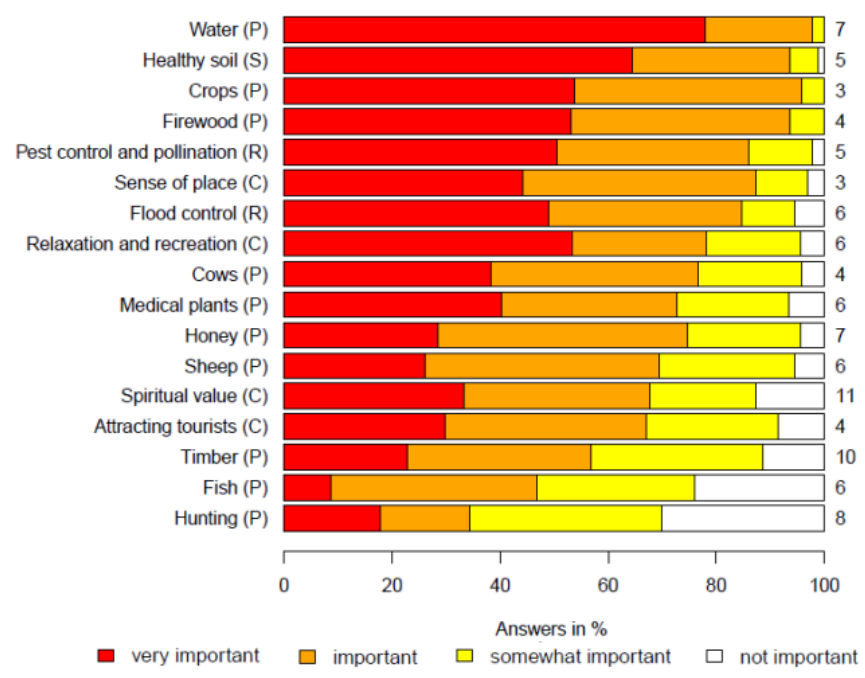

Component 2: semistructured interviews

In the summer of 2011, 50 face-to-face semistructured interviews were conducted in 5 villages, i.e., 10 in each village. For ethical reasons, we abbreviated the names of these villages as $\mathrm{AV}, \mathrm{M}, \mathrm{A}$, $\mathrm{V}$, and $\mathrm{D}$. The villages $\mathrm{M}$ and $\mathrm{V}$ had major regional actors active for a decade, i.e., nongovernment organizations (NGO) and individual persons, AV was targeted by major actors (NGO) in the past five years, sporadic activities, i.e., small initiatives, had occurred in A, and virtually no major actors had been active in $\mathrm{D}$.

The interviewees were different individuals than the people addressed by the questionnaires. The interviews were conducted by one person in Romanian or Hungarian. Detailed notes were taken, but interviews were not recorded to encourage more open and honest responses. Moreover, as this was the first step in a broader research project, the aim was to not only gather basic information about the system as a whole, but also to make the first contact with the local communities. In this context, we aimed to be less formal in our interactions with the interviewees. Interesting sentences were quoted literally by asking the interviewees to repeat them. Representatives of all relevant ethnic groups were interviewed. People were identified by randomly approaching them in the street and at their homes and then through the snowball method. Table 1 presents an overall summary of the structure of the sample. The general approach for this component was inductive and followed a broadly critical realist perspective similar to that discussed by McLaughlin and Dietz (2008), which recognized inherent linkages between human agency, social structure and dynamics, and their relationships to the environment.

Table 1. The structure of the groups studied for the environmental services (ES) survey and the semistructured interviews.

\begin{tabular}{|c|c|c|}
\hline & $\begin{array}{l}\text { Questionnaire survey for ES } \\
(\mathrm{n}=98)\end{array}$ & $\begin{array}{l}\text { Semistructured } \\
\text { interviews }(\mathrm{n}=50)\end{array}$ \\
\hline $\begin{array}{l}\text { Age (mean, } \\
\text { min-max) }\end{array}$ & $41(18-74)$ & $47(18-80)$ \\
\hline Gender & $\begin{array}{l}31 \text { Females } \\
68 \text { Males }\end{array}$ & $\begin{array}{l}28 \text { Females } \\
22 \text { Males }\end{array}$ \\
\hline Ethnic group & $\begin{array}{l}49 \text { Romanians } \\
39 \text { Hungarians } \\
7 \text { Rroma } \\
2 \text { Saxons } \\
1 \text { Foreigner }\end{array}$ & $\begin{array}{l}23 \text { Romanians } \\
7 \text { Hungarians } \\
13 \text { Roma } \\
7 \text { Saxons }\end{array}$ \\
\hline Occupation & $\begin{array}{l}33 \text { Farmers } \\
31 \text { Employees } \\
14 \text { "Workers" (e.g., carpenter, } \\
\text { break maker, mechanic) } \\
7 \text { Teachers } \\
13 \text { Other (retired, director, } \\
\text { priest) }\end{array}$ & $\begin{array}{l}22 \text { Farmers } \\
6 \text { Employees } \\
3 \text { "Workers" } \\
6 \text { Teachers } \\
12 \text { Retired } \\
1 \text { Priest }\end{array}$ \\
\hline
\end{tabular}

The interviews were structured along the following broad themes: (1) the past, which included communist-socialist times for the middle to old-aged people: "Tell me about the major events and changes of any kind, happening in the past that affected this community, including your own life". (2) The present, referring to the past five years: "Tell me about the major events and changes of any kind, happening in the last five years that affected this community, including your life". (3) The future, referring to the next decade and beyond: "How do you see the future of this village? What types of changes will occur?" (4) The main actors in the village: "Tell me about important local actors, e.g., persons, organizations, ethnic groups, and parties, in this village, and why they are important?" This last question was interpreted by all interviewees with a positive connotation. Therefore interviewees mentioned those actors whom they perceived to make a positive difference for the local community. Formal institutions, e.g., police, local council, and schools, were mentioned in various responses, typically highlighting their overall weak character in the present compared to the past. The interviews took on average 30-40 minutes. 


\section{Data analysis}

Questionnaire data were analyzed with descriptive statistics over all interviewees and villages. We performed an initial screening for grouping of interviewees and for variation related to village characteristics, but did not find any clear pattern, which was most likely because the dataset was too small for a multivariate analysis.

Interviews were analyzed using open coding techniques to determine broad themes discussed by participants (Gibbs 2007). First, we identified words or phrases that succinctly summarized key parts of the narratives. For example such words or phrases included "inability to associate," "individualism,' "trust," "aggression," "Saxons," "Roma," “jobs," "infrastructural development," "farmland," "cattle," "school," and "police.". The narratives told by interviewees were decomposed using such codes. We iteratively repeated this process and grouped or split words or phrases as necessary. In the final stage, we grouped words and phrases into four broad categories: social, e.g., "individualism," "aggression," and "trust;" institutional, e.g., "police" and "school;" economic, e.g., "cattle," "job," and "infrastructural development;" and environmental, e.g., "farmland." Based on this, we created short synthetic stories about the past, present, and future of the villages. These condensed stories were then validated by comparing them with the original narratives. Words and phrases that were mentioned at least five times, an arbitrarily set threshold, were all used to create these synthetic stories. We selected this threshold because we felt that in this way we could succinctly mirror the broad realities of the individual stories. Less frequently mentioned words and phrases were occasionally included to give a glimpse into the diversity of perceptions about a given issue. We also used one or two characteristic quotes to capture some of the wording used by the interviewees.

We noted each local actor mentioned by the interviewees, and based on these records, we grouped actors into the following seven categories: ethnic groups, e.g., when a certain ethnic group had a major effect on any aspect of community life, NGOs with an important role for the village, individuals, foreign organizations, the church and priest, farmer associations, and volunteer groups. We summarized the results in a table (Table 2), listing the types of local actors, and how many interviewees referred to them in each of the five villages.

We acknowledge that our method used for the semistructured interviews may appear partly subjective. We chose to employ it because our research was the first step of a broader research project, which involved interviews with a higher sample size for two years. This being the case, our goal was to generate a broad understanding of the social system, and more specific aspects will be addressed in subsequent research. Our findings, i.e., the synthetic stories, match well with the results gathered by subsequent interviews (Mikulcak et al. 2013), scenario workshops (J. Hanspach, T. Hartel, A. Milcu, F. Mikulcak, I. Dorresteijn, J. Loos, H. von Wehrden, T. Kuemmerle, D. Abson, A. KovácsHostyánszki, A. Báldi, and J. Fischer, unpublished manuscript), other workshops (T. Hartel, personal observation), and the results of a photo elicitation method (A. Ioana Milcu, personal observation). Based on these consistencies, we are confident that the methods used in our study were satisfactory to achieve the goals.
Table 2. Major local actors mentioned by the interviewees. Numbers show how many interviewees referred to a particular actor type in a given village, for example, two interviewees in Village A mentioned a lack of major local actors.

\begin{tabular}{|c|c|c|c|c|c|}
\hline & $\begin{array}{c}\text { Village } \\
\mathrm{M}\end{array}$ & $\begin{array}{c}\text { Village } \\
\text { A }\end{array}$ & $\begin{array}{c}\text { Village } \\
\text { V }\end{array}$ & $\begin{array}{c}\text { Village } \\
\text { AV }\end{array}$ & Village D \\
\hline $\begin{array}{l}\text { No major } \\
\text { actors }^{\dagger}\end{array}$ & & 2 & & & 8 \\
\hline $\begin{array}{l}\text { Ethnic groups } \\
\text { (Saxons) }\end{array}$ & 3 & & & & \\
\hline NGOs & 8 & 2 & 8 & 9 & \\
\hline Individuals & 4 & 5 & 2 & 5 & 1 \\
\hline $\begin{array}{l}\text { Foreign } \\
\text { organizations }\end{array}$ & & 3 & & & \\
\hline $\begin{array}{l}\text { Churches or } \\
\text { priests }\end{array}$ & 5 & & 1 & & \\
\hline $\begin{array}{l}\text { Farmer } \\
\text { associations }\end{array}$ & 2 & & & & \\
\hline $\begin{array}{l}\text { Volunteer } \\
\text { groups }\end{array}$ & 4 & & & & \\
\hline $\begin{array}{l}\text { No actors } \\
\text { mentioned }^{*}\end{array}$ & & & 2 & 1 & 1 \\
\hline
\end{tabular}

${ }^{\dagger}$ Interviewees said that there were no major actors.

* Interviewees did not mention any actors during the interviews.

\section{RESULTS}

The importance of ecosystem services to local communities Ecosystem services considered very important by most respondents were freshwater (over $75 \%$ of respondents), healthy soil ( $>65 \%)$, crops and firewood $(>50 \%)$, and cattle and medical plants ( $40 \%$; Fig. 2). In terms of cultural services, sense of place $(>45 \%)$ and relaxation and recreation $(>55 \%)$ were considered very important by many respondents. Pest control and pollination $(\sim 55 \%)$ and flood control $(\sim 45 \%)$ were considered as the most important regulating services (Fig. 2). No valuations as unimportant were associated with water, crops, and firewood, whereas fishing and hunting were most often considered unimportant ( $\sim 50 \%$ and $\sim 30 \%$, respectively; Fig. 2).

\section{Perceptions of changes: past, present, future}

\section{How the past differed from the present}

The most common social theme was related to the community and the attitude of people toward shared values and other people (referred to 27 times). The local community was perceived as stronger in the past (referred to 18 times) than in the present. "In the past it was much better from a social perspective: people were more united than today" (Romanian, 47, Village A). "In the past people were hard working, they were good neighbors, they respected each other, they were like brothers" (Saxon, 70, Village V). The Saxon ethnic group was mentioned in 28 interviews. Without exception, the Saxon era was associated with high community cohesion, principles, dignity, and respect by all members of ethnic groups interviewed in this study and in all villages. "Saxons were very organized people; there was order in those times in the village" (Roma, 70, Village A). "In the past people were more united, because of the Saxons. The Saxons were correct, valuable and punctual people" (Hungarian, 70, Village 
D). Some interviewees recognized that in the past individual freedom was more limited than currently (11). "The past was much worse than the present: especially because there were far fewer opportunities for people to take initiative than today" (Saxon, 47, Village V). Institutions, e.g., local governance, police, church, and school, were referred to 21 times in the narratives. The institutions and their representatives were perceived to have a higher authority in the past than at present (7). There were more cultural events in the past (6) and more jobs (25) than currently. The stability of jobs and income was higher in the past relative to present (11), even though the purchasing power of money was lower in the past than at present (3). "During communism people had work, all were employed in an obligatory way" (Romanian, 40, Village AV). "In the past it was not as hard to survive from one day to the next compared to today" (Roma, 60, Village AV). Farmlands were used, cleared, and maintained in the past, compared to the present when they are increasingly being abandoned (5).

\section{The present}

The most common social themes dominating the present were the disintegration of the local community (9) caused by the inability of people to cooperate (17), increasing individualism (12), ethnic fragmentation (5), and the formation of interest groups (5). "People don't work together, can't decide together." (Hungarian, 70 , Village D). The importance of NGO activity for some villages, e.g., restoration and tourism, was commonly mentioned (15). Some people were aware of the existence of specialization courses (4) and an increase in the regional image of their village (2) because of NGO activity. "The specialization courses recently organized by the 'Organization $\mathrm{X}$ ' were initially seen with skepticism by locals, even by me, but later people liked them, and it was a success overall for the village" (Male, 65, Village AV). Many local institutions were seen to have low authority (5), be corrupt, and characterized by poor leadership (7). Jobs (9) and working opportunities (12) were seen to be lacking. Agriculture was characterized as largely traditional (25), but some people reported a gradual shift toward mechanized agriculture (7). When people talked about traditional agriculture, it was largely in the context of poverty and a lack of other options: "Those people with money use mechanized agriculture. Poor people use traditional agriculture" (Romanian, 23, Village A). Young people often left the village for seasonal or permanent work (10). By contrast, people from three villages (Village $\mathrm{AV}$, Village $\mathrm{M}$, and Village $\mathrm{V}$ ) reported increases in tourism (10) and with this, some opportunities to generate extra income (7), an increase in the number of restored houses (4), and improvements to public infrastructure (4). "There are employment opportunities in Village $\mathrm{M}$, we have farms and the orchard where people work. There are milk collection centers where people work" (Romanian, 36, Village M). "The present brings a lot more opportunities for people than the past: there are many initiatives in the village and if people really want something they can achieve it if they are persistent, open-minded and hard working" (Saxon, 47, Village V). Members of the Roma ethnic group were associated with poverty, demographic growth, conflicts, and ethnic and economic marginalization (8). An illustrative quote for the marginalization of this ethnic group comes from the village M: "Look, the road ends here" (Roma, 41, Village M; referring to the situation when paving of the road ended at the border of their neighbourhood).
In terms of the environment, much agricultural land is being abandoned (6) because of economic unprofitability and an ageing population. "It is easier to earn $1000 \mathrm{RON}$ in a factory today than from agriculture" (Male, 65, Village AV). "Agriculture is still traditional. The gasoline is very expensive ... many lands are abandoned" (Hungarian, 70, Village D).

\section{The future}

Some people expected that indifference (5) and individualism (6) would increase and the young would continue to emigrate (9). "Look around, and see... The future will mean much more degradation, depopulation. People are unable to coalize, to do something good for their lives. We need a lot of help from the outside" (Male, 65, Village AV). Some people believed that the future would be highly dependent on appropriate leadership (10). Employment prospects would remain relatively poor (5), and the economic future of the villages would depend on people's ability to cooperate (14). This was captured by a 72-year-old Saxon who said: "I don't blame times. I blame people." In two of the villages (Village $\mathrm{V}$ and Village $\mathrm{M}$ ), the possibility to generate alternative incomes could increase (5), especially as a result of increased tourism and other initiatives (11). In Village $\mathrm{M}$ and Village V, more people were optimistic regarding their future than in the other three villages. Cultural tourism and ecotourism were perceived by interviewees as important for the future socioeconomic state of these villages. They felt that many initiatives already existed, creating fertile ground for complementary seasonal incomes: "Usually people generate small incomes while working a little bit in many areas in the village: for example I work in the school, I work in tourism and agriculture" (Romanian, 40, Village M).

\section{Local actors}

The local individuals and NGOs were mentioned as the most important local actors (Table 2). Cultural tourism and restoration of houses were considered particularly important in Village V. The most common activities associated with NGOs were: helping in building restoration, construction of milk collection centers, organization of courses for farmers in agro-tourism and languages, and various other initiatives to help in developing marketing and income opportunities. For example, the sock making association in Village $\mathrm{V}$ contributed not only to the livelihoods of its members, currently $\sim 70$ women, but also to a sense of common purpose for the community as a whole. Interviewees from Village $\mathrm{V}$ and Village $\mathrm{AV}$ also suggested that the presence of a major NGO in the village gave a strong incentive for people to cooperate. Negative references to the activity of NGOs were made by five interviewees, the main reason being the perceived inability of these actors to involve a larger part of the community or to extend their activities to address other social and economic issues.

\section{DISCUSSION}

Our results can be summarized as follows: first, three provisioning ecosystem services, i.e., water, crops, and firewood, one supporting service, i.e., healthy soils, and one cultural ecosystem service, i.e., the value of landscapes for relaxation and recreation, were considered very important by more than $50 \%$ of the respondents. Second, the traditional cultural landscape is undergoing major social and economic changes. People reported sharp increases in individualism, lack of trust, conflicts, and 
poverty after the 1989 revolution. Third, people from villages with a diversity of strong local leaders appeared to have more positive perceptions about the current and future socioeconomic states of their villages.

Our finding regarding the importance of ecosystem services is in line with other studies showing that rural communities show high appreciation toward provisioning ecosystem services (Iftekhar and Takama 2008, Agbenyega et al. 2009, Martín-López et al. 2012), in contrast to urbanized communities who mostly appreciate the aesthetic and recreational values of landscapes (Martín-López et al. 2012, Plieninger et al. 2013). Industrial activity and opportunities for stable jobs in the study region are poor; therefore the majority of people still largely depend on provisioning ecosystem services in their everyday lives (Fischer et al. 2012, Mikulcak et al. 2013). At least some of the rural inhabitants practice subsistence farming because of a lack of other options at local and regional scales (Mikulcak et al. 2013). A similar return to traditional practices caused by poor economic conditions was described in Spain for transhumant shepherds (Oteros-Rozas et al. 2013).

Moreover, the semistructured interviews revealed a number of social and economic issues challenging local communities, such as the weakening of local communities and institutions, corruption, conflicts, an overall lack of job opportunities, and a general sense of poverty. The Saxon cultural landscape and its communities went through several social, institutional, political, and economic changes during the past decades. It is possible that these relatively rapid and drastic ethnic and cultural changes negatively affected the personal identification of people with their land, ecological respect,, and caretaking (defined as ecological embeddedness in Whiteman and Cooper 2000), which had been very strong historically in previous times (Dorner 1910). More recently, with accession to the European Union, people's aspirations, needs and behaviours are increasingly influenced by Western culture. Many young people have emigrated permanently or temporarily (Horáth 2008). These many changes coupled with a poor economic environment and weak formal institutions could erode the social capital of rural communities (sensu Adger 2003, Hero 2003).

Traditionally, much of people's energy went into the active maintenance of those elements of the landscape that provided ecosystem services for them, e.g., clearing of shrubs and dead trees from the pastures and the managing and guarding the forest (Dorner 1910). At present, the landscape continues to be important for many rural inhabitants, but many aspects of modern life, e.g., access to information, formal education, transport, and health care, depend on financial capital and infrastructure. Ecosystem services, including provisioning services, which once were at the heart of the rural institutions and communities (Dorner 1910, Oroszi 2004), can no longer satisfy the modern needs and aspirations of people.

Interviewees in three villages identified local initiatives that aimed to support small-scale farmers, created incentives for them to associate with, and assisted them in developing local businesses to generate extra income. Regionally important NGOs such as the Mihai Eminescu Trust and the ADEPT Foundation assist farmers in various ways, e.g., in restoring traditional buildings, in accessing agri-environment payments, or by lobbying internationally for cultural and ecological tourism. Similarly, Local Action Groups are new associations of rural inhabitants that bring together various local actors from neighboring villages to develop a common vision for regional development. The more optimistic views about the future in communities with a range of initiatives underline that diverse and pluralistic leadership can contribute significantly to the adaptive capacity and social cohesion of communities (Goodman et al. 1998, Norris et al. 2008, Islam and Morgan 2011).

\section{CONCLUSION}

In conclusion, rural communities in the cultural landscape of Southern Transylvania rate a number of provisioning ecosystem services as being very important for their everyday lives. Rural communities, however, are affected by a large number of socioeconomic challenges. Traditional land-use practices, which have maintained ecologically valuable landscapes, seem to be the result of poverty and lack of other opportunities for many rural inhabitants rather than resulting from an active desire to maintain traditional landscapes. With aspirations shifting increasingly toward Western ideals, reliance on local provisioning ecosystem services is not a choice actively made by most people. Environmental resource managers, conservation biologists, and those advocating Western-style socioeconomic development need to consider simultaneously the social and ecological challenges associated with economic development in this region.

Responses to this article can be read online at: http://www.ecologyandsociety.org/issues/responses. $\mathrm{php} / 6333$

\section{Acknowledgments:}

We thank all interviewees for taking the time to talk to us. We appreciate the useful comments of Dr. Kate Sherren on the manuscript. Research was funded via a Sofja Kovalesvkaja Award to JF, granted by the Alexander von Humboldt Foundation and sponsored by the German Ministry of Research and Education. Tibor Hartel was supported by an Alexander von Humboldt postdoctoral fellowship.

\section{LITERATURE CITED}

Adger, W. N. 2003. Social capital, collective action, and adaptation to climate change. Economic Geography 79:387-404.

Agbenyega, O., P. J. Burgess, M. Cook, and J. Morris. 2009. Application of an ecosystem function framework to perceptions of community woodlands. Land Use Policy 26:551-557. http://dx. doi.org/10.1016/j.landusepol.2008.08.011

Akeroyd, J. R., and N. Page. 2007. The Saxon villages of southern Transylvania: conserving biodiversity in a historic landscape. Pages 199-210 in D. Gafta and J. R. Akeroyd, editors. Nature conservation: concepts and practice. Springer, Berlin, Germany. http://dx.doi.org/10.1007/978-3-540-47229-2_21

Baltag, G. 2004. Sighisoara, Schässburg, Segesvár. Ed. Nemira Napocae, Cluj Napoca, Romania (in Romanian). 
Bell, S., A. Montarzino, P. Aspinall, Z. Peneze, and O. Nicodemus. 2009. Rural society, social inclusion and landscape change in Central and Eastern Europe: a case study of Latvia. Sociologia Ruralis 49:295-326. http://dx.doi.org/10.1111/j.1467-9523.2009.00480. $\underline{\mathrm{X}}$

Bugalho, M. N., M. C. Cladeira, J. S. Pereira, J. Aronson, and J. G. Pausas. 2011. Mediterranean cork oak savannas require human use to sustain biodiversity and ecosystem services. Frontiers in Ecology and the Environment 9:278-286. http://dx.doi. org/10.1890/100084

Dorner, B. 1910. The agriculture of Transylvanian Saxons. Győr, Hungary (in Hungarian).

Fischer, J., T. Hartel, and T. Kuemmerle. 2012. Conservation policy in traditional farming landscapes. Conservation Letters 5:167-175. http://dx.doi.org/10.1111/j.1755-263X.2012.00227.x

Foley, J. A., R. DeFries, G. P. Asner, C. Barford, G. Bonan, S. R. Carpenter, F. S. Chapin, M. T. Coe, G. C. Daily, H. K. Gibbs, J. H. Helkowski, T. Holloway, E. A. Howard, C. J. Kucharik, C. Monfreda, J. A. Patz, I. C. Prentice, N. Ramankutty, and P. K. Snyder. 2005. Global consequences of land use. Science 309:570-574. http://dx.doi.org/10.1126/science.1111772

Gibbs, G. R. 2007. Analysing qualitative data. Sage, Thousand Oaks, California, USA.

Goodman, R. M., M. A. Speers, K. Mcleroy, S. Fawcett, M. Kegler, E. Parker, S. R. Smith, T. D. Sterling, and N. Wallerstein. 1998. Identifying and defining the dimensions of community capacity to provide a basis for measurement. Health Education and Behavior 25:258-278. http://dx.doi.org/10.1177/109019819802500303

Halada, L., D. Evans, C. Romão, and J.-E. Petersen. 2011. Which habitats of European importance depend on agricultural practices? Biodiversity and Conservation 20:2365-2378. http://dx. doi.org/10.1007/s10531-011-9989-Z

Hero, R. E. 2003. Social capital and racial inequality in America. Perspectives on Politics 1:113-122. http://dx.doi.org/10.1017/ $\underline{\mathrm{S} 1537592703000094}$

Horváth, I. 2008. The culture of migration of rural Romanian youth. Journal of Ethnic and Migration Studies 34:771-786. http:// dx.doi.org/10.1080/13691830802106036

Iftekhar, M. S., and T. Takama. 2008. Perceptions of biodiversity, environmental services, and conservation of planted mangroves: a case study of Nijhum Dwip Island, Bangladesh. Wetlands Ecology and Management 16:119-137. http://dx.doi.org/10.1007/ s11273-007-9060-8

Institutul National de Statistica/National Institute of Statistics. 2011. Population and housing census, 2011. Institutul National de Statistica, Bucharest, Romania. [online] URL: http://www. recensamantromania.ro/en/

Islam, M. R., and W. J. Morgan. 2012. Non-governmental organizations in Bangladesh: their contribution to social capital development and community empowerment. Community Development Journal 47(3):369-385. http://dx.doi.org/10.1093/ cdj/bsr024
Liu Y., M. Duan, and Z. Yu. 2013. Agricultural landscapes and biodiversity in China. Agriculture, Ecosystems and Environment 166:46-54. http://dx.doi.org/10.1016/j.agee.2011.05.009

Martín-López, B., I. Iniesta-Arandia, M. García-Llorente, I. Palomo, I. Casado-Arzuaga, D. García Del Amo, E. GómezBaggethum, E. Oteros-Rozas, I. Palacios-Agundez, B. Willaarts, J. A. González, F. Santos-Martín, M. Onaindia, C. SantiagoLópez, and C. Montes. 2012. Uncovering ecosystem service bundles through social preferences. PLoS ONE 7(6):e38970. http://dx.doi.org/10.1371/journal.pone.0038970

McLaughlin, P., and T. Dietz. 2008. Structure, agency and environment: toward an integrated perspective on vulnerability. Global Environmental Change 18:99-111. http://dx.doi.org/10.1016/ j.gloenvcha.2007.05.003

Mikulcak, F., J. Newig, A. I. Milcu, T. Hartel, and J. Fischer. 2013. Integrating rural development and biodiversity conservation in central Romania. Environmental Conservation 40:129-137. http:// dx.doi.org/10.1017/S0376892912000392

Millennium Ecosystem Assessment (MEA). 2005. Millennium Ecosystem Assessment. Millennium Ecosystem Assessment, Buenos Aires, Argentina. [online] URL: http://www. millenniumassessment.org/en/index.html

Molnár, Z. 2012. Classification of pasture habitats by Hungarian herders in a steppe landscape (Hungary). Journal of Ethnobiology and Ethnomedicine 8:28. http://dx.doi.org/10.1186/1746-4269-8-28

Nägler, T. 1992. The arrival of the Saxons in Transylvania (in Romanian). Kriterion, Bucharest, Romania.

Norris, F. H., S. P. Stevens, B. Pfefferbaum, K. F. Wyche, and R. L. Pfefferbaum. 2008. Community resilience as a metaphor, theory, set of capacities, and strategy for disaster readiness. American Journal of Community Psychology 41:127-150. http:// dx.doi.org/10.1007/s10464-007-9156-6

Oroszi, S. 2004. The forest management of Transylvanian Saxons, Budapest (in Hungarian). Erészeti Egyesület, Erdészettörténeti Szakosztály, Budapest, Hungary.

Oteros-Rozas, E., B. Martín-López, C. A. López, I. Palomo, and J. A. González. 2013. Envisioning the future of transhumant pastoralism through participatory scenario planning: a case study in Spain. Rangeland Journal 35:251-272. http://dx.doi. org/10.1071/RJ12092

Plieninger, T., and C. Bieling, editors. 2012. Resilience and the cultural landscape: understanding and managing change in humanshaped environments. Cambridge University Press, Cambridge, UK. http://dx.doi.org/10.1017/CBO9781139107778

Plieninger, T., S. Dijks, E. Oteros-Rozas, and C. Bieling. 2013. Assessing, mapping, and quantifying cultural ecosystem services at community level. Land Use Policy 33:118-129. http://dx.doi. org/10.1016/j.landusepol.2012.12.013

Plieninger, T., M. Schaar. 2008. Modification of land cover in traditional agroforestry system in Spain: processes of tree expansion and regression. Ecology and Society 13(2): 25. [online] URL: http://www.ecologyandsociety.org/vol13/iss2/art25/ 
Ranganathan J., R. J. R. Daniels, M. D. S. Chandran, P. R. Ehrlich, and G. C. Daily. 2008. Sustaining biodiversity in ancient tropical countryside. Proceedings of the National Academy of Sciences 105:17852-17854. http://dx.doi.org/10.1073/pnas.0808874105

Solymosi, K. 2011. Indicators for the identification of cultural landscape hotspots in Europe. Landscape Research 36:3-18. http:// dx.doi.org/10.1080/01426397.2010.530647

Sutcliffe, L., I. Paulini, G. Jones, R. Marggraf, and N. Page. 2013. Pastoral commons use in Romania and the role of the common agricultural policy. International Journal of the Commons 7:58-72. [online] URL: http://www.thecommonsjournal.org/index.php/ ijc/article/view/URN\%3ANBN\%3ANL \%3AUI\%3A10-1-114405/313

Takeuchi, K. 2010. Rebuilding the relationship between people and nature: the Satoyama initiative. Ecological Research 25:891-897. http://dx.doi.org/10.1007/s11284-010-0745-8

Verdery, K. 2003. The vanishing hectare: property and value in postsocialist Transylvania. Cornell University Press, Ithaca, New York, USA.

Whiteman, G., and W. H. Cooper. 2000. Ecological embeddedness. Academy of Management Journal 43:1265-1282. http://dx.doi.org/10.2307/1556349

Wilson, J. B., R. K. Peet, J. Dengler, and M. Pärtel. 2012. Plant species richness: the world records. Journal of Vegetation Science 4:796-802. http://dx.doi.org/10.1111/j.1654-1103.2012.01400.x 
Appendix 1. The questionnaire used to assess the importance of various ecosystem services for the inhabitants of the rural landscape.

Questionnaire nr.:

Age and ethnic origin:

Day:

Profession:

Village:

\section{Benefits people obtain from the surrounding environment}

People obtain a number of benefits from the surrounding environment, in multiple forms.

How important are in your village the following benefits provided by the natural environment? Please mark in the above table.

\begin{tabular}{|l|l|l|l|l|l|}
\hline & $\begin{array}{l}\text { Not } \\
\text { important }\end{array}$ & $\begin{array}{l}\text { Somewhat } \\
\text { important }\end{array}$ & Important & $\begin{array}{l}\text { Very } \\
\text { important }\end{array}$ & I don't know \\
\hline Crops & & & & & \\
\hline Firewood & & & & & \\
\hline Sense of place & & & & & \\
\hline Honey & & & & & \\
\hline $\begin{array}{l}\text { Attracting } \\
\text { tourists }\end{array}$ & & & & & \\
\hline Sheep & & & & & \\
\hline Relaxation and \\
recreation
\end{tabular}

